\title{
Punching Above its Weight: Life Cycle Energy Accounting and Environmental Assessment of Vanadium Microalloying in Reinforcement Bar Steel
}

Pranav Pradeep Kumar ${ }^{1,2}$, David A. Santos ${ }^{3,4}{ }^{\S}$ Erick J. Braham ${ }^{3,4}$, Diane G. Sellers ${ }^{3,4}$, Sarbajit Banerjee $^{3,4}$ * and Manish K. Dixit ${ }^{2 *}$

\$These authors contributed equally to this work

*Corresponding author: mdixit@tamu.edu

${ }^{1}$ Zachry Department of Civil Engineering, Texas A\&M University, College Station, TX, 77843-3255, USA

${ }^{2}$ Department of Construction Science, Texas A\&M University, College Station, TX, 77843-3255, USA

${ }^{3}$ Department of Chemistry, Texas A\&M University, College Station, TX, 77843-3255, USA

${ }^{4}$ Department of Materials Science and Engineering, Texas A\&M University, College Station, TX, 77843-3255, USA

\begin{abstract}
Steel-reinforced concrete is ubiquitously used in construction across the world. The United Nations estimates that the worldwide energy consumption of buildings accounts for $30-40 \%$ of global energy production, underlining the importance of the judicious selection of construction materials. Much effort has focused on the use of high-strength low-alloy steels in reinforcement bars whose economy of materials use is predicated upon improved yield strengths in comparison to low-carbon steels. While microalloying is known to allow for reduced steel consumption, a sustainability analysis in terms of embodied energy and $\mathrm{CO}_{2}$ has not thus far been performed. Here we calculate the impact of supplanting lower grade reinforcement bars with higher strength vanadium microalloyed steels on embodied energy and carbon footprint. We find that the increased strength of vanadium microalloyed steel translates into substantial material savings over mild steel thus reducing the total global fossil carbon footprint by as much as $0.385 \%$. A more granular analysis pegs savings for China and the European Union at 1.01 and $0.19 \%$, respectively, of their
\end{abstract}


respective emissions. Our cradle-to-gate analysis provides an accounting of the role of microalloying in reducing the carbon footprint of the steel and construction industries and highlights the underappreciated role of alloying elements.

Keywords: low-alloy steel; construction; reinforcement bar steel; vanadium; life cycle assessment; metal; microalloying; building codes

\section{Introduction}

The built environment represents a substantial source of greenhouse emissions and consumes an inordinate proportion of available energy and natural resources (Houvilla, 2007; U.S. Department of Energy, 2008; U.S. Energy Information Administration (EIA), 2020). The United Nations estimates that the worldwide energy consumption of buildings accounts for $30-40 \%$ of global energy production annually; notwithstanding improvements in sustainable building practices (Houvilla, 2007), a sharply upwards trajectory is projected with increasing urbanization. The construction and operation of buildings consumes $16 \%$ of water resources, $25 \%$ of harvested wood, and $40 \%$ of aggregates, thereby considerably depleting local and global ecosystems of natural resources (Dixit, 2017). Much recent effort has focused on reducing the carbon footprint of the built environment during construction, operation, and end-of-life disposal or reuse/recycling. Arguably one of the intrinsic difficulties associated with this effort is to simultaneously reduce values of both embodied energy and operational energy, which often have countervailing dependencies. Central to the adoption of sustainable building practices is the design and deployment of materials within structural elements, architectural facades, and functional components that either can be sourced with minimal impact on the environment and/or drastically reduce operational energy consumption (Bajpayee et al., 2020; Bechthold and Weaver, 2017; 
Hasanbeigi et al., 2012). Obtaining a rigorous accounting of materials across their life cycle is imperative to inform the selection of building materials and requires consideration of the embodied energy and $\mathrm{CO}_{2}$ implications of materials production and transportation, quantities required to achieve specific functionality, constraints arising from use of the said material, and the often entangled changes in the requirements for other materials or components. In this article, we focus on a mainstay of the construction industry, reinforcement bar steels, and examine the implications of vanadium microalloying, a ubiquitous strengthening mechanism, (Babakhani et al., 2012; Baker, 2009; Baker and Baker, 2016; Korchynsky and Paules, 1989; Zajac et al., 1998) from the perspective of the impact on material use, embodied energy and carbon footprint arising from supplanting lower grade reinforcement bars with higher strength vanadium microalloyed steels.

\subsection{Embodied Energy and Carbon Footprint of the Built Environment}

While much research has focused on the identification of building elements that reduce operational energy consumption, recent publications have illustrated that embodied energy contributes significantly to the total energy use of the built environment across its life cycle (Copiello, 2016; Davies et al., 2014; Plank, 2008). Embodied energy over a life cycle of a building

can be further divided into Initial Embodied Energy (IEE), Recurrent Embodied Energy (REE), and Demolition Energy (DE). IEE covers embodied energy contributions during the construction phase due to material usage and construction and transportation processes, whereas REE pertains to materials and processes used in maintenance, replacement and repairs during the building life cycle (Dixit, 2019). Building materials account for over $90 \%$ of the total embodied impact of construction (IEE), and their judicious selection is thus of paramount importance to reducing the enormous energy and environmental footprint of construction (Bajpayee et al., 2020; Dixit, 2017; Hasanbeigi et al., 2012). 
Building materials such as concrete and steel extract a heavy toll on natural resources. Considerable embodied and operational energy expenditures are furthermore incurred during production, manufacture, usage, construction, and maintenance on account of these key two structural materials. Indeed, some estimates suggest that the production of cements accounts for approximately $4 \%$ of global greenhouse emissions. However, the longevity, structural performance, and seismic resilience of reinforced concrete has few parallels and this combination of materials thus continues to find widespread use (Guardigli, 2014). Similarly, steel is used as a means of reinforcement across large swathes of the construction industry but incurs a considerably larger energy and carbon emission burden as compared to other building materials given the traditionally energy intensive nature of steel production. About half of the steel produced each year goes towards the construction of buildings and infrastructure (American Iron and Steel Institute, 2016; Nakoryakova et al., 2019). Increasing urbanization has led to a sharply upwards trajectory, which bodes poorly for the carbon footprint of the construction industry. Since 2000, global steel production has doubled, reaching a record high of 1700 million metric tons (mMT) in 2017 (Dixit, 2019). Despite efficiencies gained by upcycling of by-products such as slag, a striking 2 tons of $\mathrm{CO}_{2}$ are generated for every ton of steel produced (World Steel Association, 2018). From a global perspective, over $9 \%$ of worldwide $\mathrm{CO}_{2}$ emissions are directly attributable to steel production.(Moynihan and Allwood, 2012) According to the International Energy Agency (IEA), the demand for steel will double by 2050 , necessitating a sharp reduction in the emission of carbon per unit of steel production or the implementation of alternative construction approaches that enable reduced steel consumption (Moynihan and Allwood, 2012).

\subsection{Vanadium Microalloyed Steels: Higher Strengths Enable Reduced Steel Consumption}


High-strength-low-alloy (HSLA) steels have emerged as an attractive class of strengthened steels, which, by dint of their higher yield strength, offer considerable economy of materials use in structural applications in construction as well as other industries such as automotive. In contrast to conventional low-carbon steels, HSLA steels offer higher yield strength, improved elongation performance, enhanced resistance to brittle fracture, and greater resistance to corrosion, thereby satisfying ductility, weldability, and toughness criteria for structural applications (Chen et al., 2009; Garcia, 2016). HSLA steels are prepared through metallurgical processes that enable precise control over microstructure and dislocation density through alloying, refinement of grain size, the inclusion of nanoscopic precipitates, programmed tempering profiles, and thermomechanical treatments (Baker and Baker, 2016; Garcia, 2016; Montemarano et al., 1986; Skobir, 2011). Micro-alloyed ferrite-pearlite steels are ubiquitously used in structural applications and typically contain relatively small additions (usually less than $0.10 \%$ ) of carbonitride-forming elements (Skobir, 2011). Yield strengths as high as $1000 \mathrm{MPa}$ are accessible from microalloying, which renders this approach the primary strengthening mechanism for most structural applications (Baker, 2016; Xie et al., 2014).

In construction applications, the primary consideration for the selection of a specific ferrous alloy composition for reinforcement bars is the strength-to-weight ratio, often quantified by the yield strength. Indeed, the classification of reinforcing bars in accordance with British (BS 4449:1997, 1997; Steel for the Reinforcement of Concrete-Weldable Reinforcing Steel-Bar, Coil and Decoiled Product - Specification, 2005) and European (EN 1992-1-1, 2004) standards and the nomenclature denoted here directly reflect the minimum permissible yield strength (BS 4449:1997, 1997; EN 1992-1-1, 2004; Steel for the Reinforcement of Concrete-Weldable Reinforcing Steel-Bar, Coil and Decoiled Product - Specification, 2005). A higher-grade 
reinforcement bar implies that substantially less steel can be used to achieve the same structural performance in load-bearing applications. The advantages of high-strength steels have been notably demonstrated in the case of automotive frameworks by the American and International Iron and Steel Institutes through a light weighting initiative wherein weight savings from utilization of HSLA steels resulted in a 51\% reduction in energy consumption over the life cycle of a vehicle (Crooks and Miner, 1996; Smith et al., 2002). A detailed computational and experimental report directed by the United States Army Research -Laboratory (ARL) demonstrated up to $17 \%$ material savings resulting from the use of vanadium microalloyed HSLAs in long-span joists and girders (Beatty, 2011). A previous study also suggests that the addition of vanadium to steel reinforcing bars reduces the amount of carbon needed to attain a particular yield strength and enables processing at lower temperatures as compared to niobium steel, which is a result of the fundamentally different strengthening mechanisms, precipitation in vanadium steel and fine grain size for niobium steel (Sage, 1984). While considerable economy of materials use derives from adoption of HSLAs in construction applications, an accurate assessment of how this translates to savings in energy and carbon remains to be determined.

In this article, we focus on analyzing the embodied energy and carbon footprint derived from microalloying with vanadium, a commonly used strengthening mechanism that has widespread global use. Microalloying with relatively small amounts of vanadium, ca. $0.02-0.2 \%$, brings about considerable improvements in yield strength, ductility, and seismic performance (G.Davies, 1978; Gündüz and Cochrane, 2005; Milbourn and Yu, 2010; Show et al., 2010). Vanadium incorporation strengthens steel through formation of nanoscopic precipitates of vanadium nitrides, carbides, and carbonitrides during the austenite to ferrite transformation (Baker, 2009; Garcia, 2016; Glodowski, 2014; Show et al., 2010). Additional benefits, often manifested 
as improved hardness, can be achieved through grain refinement by nucleation of ferrite on vanadium carbonitride precipitates (Rehder, 2015; Wang et al., 2018). The effectiveness of vanadium in improving yield strength stems from a fundamental thermodynamic property, the excellent solubility of the vanadium inclusions in austenite as a result of favorable enthalpies of mixing (Glodowski, 2014; Parija et al., 2018; Rehder, 2015). In other words, a larger fraction of miscible vanadium in solution prior to rolling promotes a higher precipitation efficiency during the ferrite transformation (Li and Milbourn, 2015; Taylor, 1995). Furthermore, the benefits of high solubility translate directly to improved ductility and lower requirements for rolling loads, which improves processing efficiencies and the overall energy use in comparison to alternative microalloying strategies.

\subsection{Energy and Carbon Costs Associated with Production of Vanadium Precursors}

A rigorous life cycle accounting of embodied energy and carbon for vanadiummicroalloyed steels requires consideration not just of the economy of materials use stemming from the increased yield strength accessible upon microalloying but also the quantitation of the energy and carbon expended in the production of vanadium precursors (which can be classified further as primary production, co-production, and recycling). In $2017,74 \%$ of vanadium feedstock production occurred through co-production during steel making operations, with the remaining balance coming from primary production directly from vanadium-bearing magnetite ores (14\%), and secondary $(12 \%)$ production from sedimentary vanadium largely found in oil residues or recovered from spent catalysts (Bushveld, 2018). In a typical co-production process, vanadiumcontaining pig iron is processed in an electric arc furnace for the concomitant production of steel and vanadium-bearing slag. Subsequent processing converts extracted vanadium into 
ferrovanadium or nitrides, which are used as precursors for the preparation of different grades of HSLA steels (Bauer, 2012; Weber et al., 2018).

Quantities of energy use and $\mathrm{CO}_{2}$ production from the vanadium production have been estimated in an extensive cradle-to-gate analysis published by Eckelman and colleagues (Synthesis, 2014). Briefly, these authors have compiled an extensive life cycle inventory based on existing literature taking into account primary, secondary and co-production methods of vanadium extraction. Embodied energy and carbon values were estimated based on aggregated mining, concentration, melting, and transportation data. These authors arrive at the costs of $33.1 \mathrm{~kg} \mathrm{CO} / \mathrm{kg}$ $\mathrm{V}$ and $516 \mathrm{MJ} / \mathrm{kg} \mathrm{V}$ for embodied carbon and energy, respectively. A recent life cycle analysis

for a hypothetical vanadium redox flow battery estimates $39.1 \mathrm{~kg} \mathrm{CO}_{2} / \mathrm{kg} \mathrm{V}_{2} \mathrm{O}_{5}$ based on the coproduction of vanadium from a deposit in South Africa, which is in good agreement with the value reported by Eckelman and collegues (Weber et al., 2018). It is important to note that these numbers reflect upper bounds since much of United States' vanadium extraction comes from recycled products, which likely lowers the overall environmental impact of vanadium. Vanadium suppliers such as BlackRock Metals are striving to further minimize environmental impacts from vanadium production through use of hydroelectricity predicting as much as $61 \%$ savings over traditional methodologies (BlackRock Metals: Life Cycle Assessment of Vanadium, 2014).

\subsection{Quantifying the Embodied Energy and Carbon Impact of Vanadium Microalloying}

In 2017, approximately $235 \mathrm{mMT}$ of steel were used to produce concrete reinforcing bars a substantial proportion of which incorporated microalloying as the primary strengthening mechanism (World Steel Associaiton, 2018). Most recently, the successful adoption of new rebar standards in China has led to a large increase in the consumption of vanadium. In 2017, the global 
average intensity of vanadium use in steel reached $0.053 \mathrm{~kg} \mathrm{~V} / \mathrm{MT}$ steel (Bushveld, 2018). While the benefits of vanadium microalloying in enhancing functional properties are well documented, a comprehensive carbon and energy accounting of the role of microalloying has not thus far been performed. Indeed, such a study is urgently needed as the construction industry seeks to directly address the costs of embodied energy and carbon footprint of construction, which have remained substantial and largely undiminished over the last several decades. Sustainable building practices require the design of load-bearing structural materials with reduced weight-to-strength ratios; microalloying provides a promising route to increased economy of materials use, which further has a knock-on effect in terms of reduced transportation costs, construction costs, and increased building resilience. A comprehensive accounting of the costs and benefits of vanadium microalloying, formulated in terms of embodied energy and carbon footprint, further considering historical data and future projections, is imperative to document the key (often underappreciated) role that vanadium plays in enhancing the sustainability of the steel manufacturing as well as construction industry.

\section{Research Methods}

In this article, our primary goal is to (1) estimate the embodied energy and carbon of vanadium-microalloyed high-strength reinforcement bars and (2) calculate potential savings with respect to mild steel. Life cycle assessment has been performed using the literature, data inventories, and market data collated from trade organizations in the steel and vanadium industry (World Steel Association and Vanitec, respectively). The study incorporates the following 5-step process detailed in the sections below and further summarized in the flowchart sketched in Figure 1: (1) Development of a structural equivalence model in order to determine the quantities 
of steel and concrete required to obtain the same load-bearing capacity when using reinforcement bars of different yield strengths. (2) development of a machine learning model using available literature data to relate yield strength to vanadium content; (3) creation of a life cycle assessment (LCA) model by gathering data pertaining to the embodied energy and carbon costs of steel, concrete, and vanadium from literature reports and LCA databases; (4) calculation and comparison of the embodied energy use and carbon footprint of vanadium micro-alloyed steels with respect to mild steel; and (5) estimation of the total carbon and energy benefits of microalloying around the world and by region by extrapolating unit benefits using geographically segmented market data gathered from trade organizations.

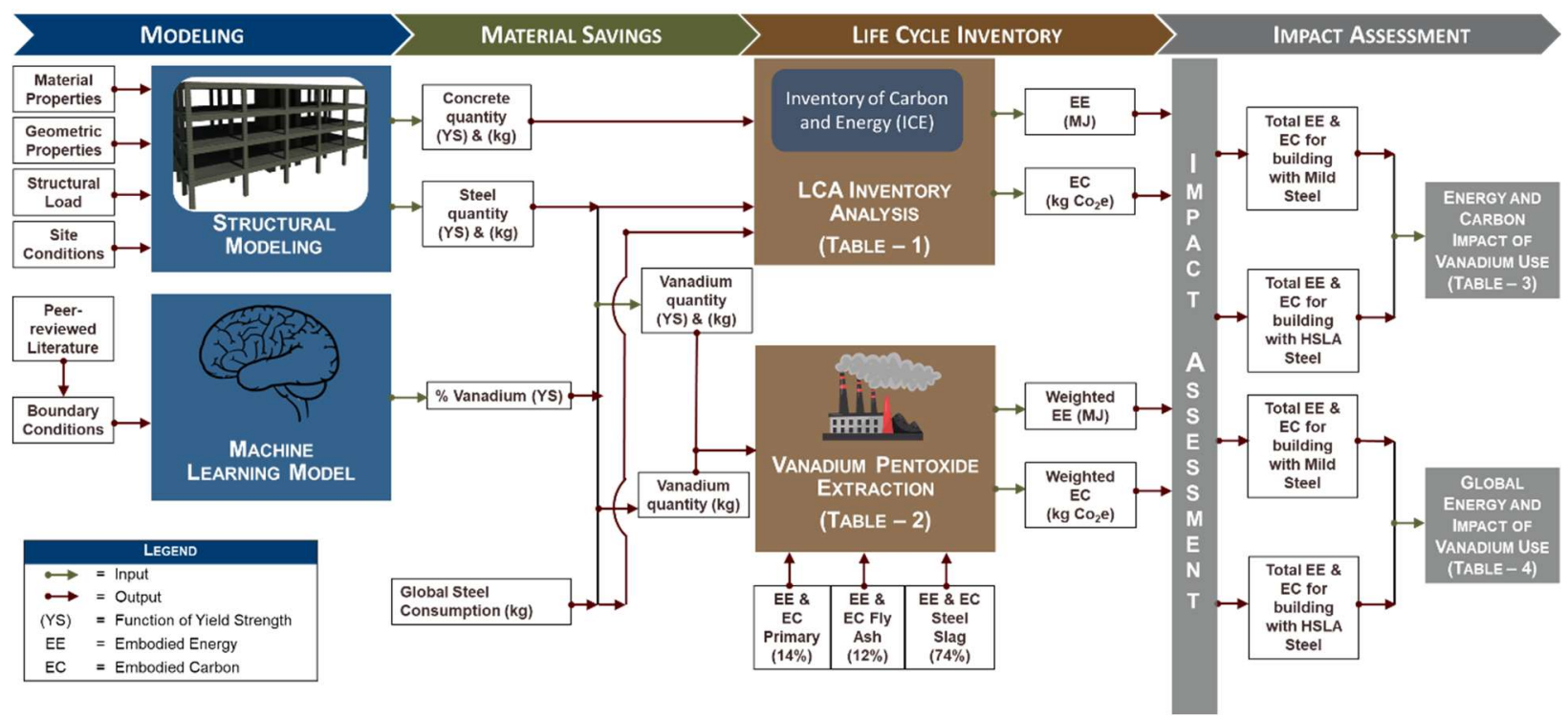

Figure 1: Flow chart of methodology adopted for life cycle assessment. Structural modeling is used to determine equivalences in load bearing capacity between different grades of rebar, enabling quantitation of savings in steel consumption upon vanadium microalloying. A machine learning model is used to define the dependence of yield strength on vanadium content for specific alloy compositions aggregating a large number of trials mined from the published literature. Materials savings are translated to embodied energy and carbon savings using LCA databases in a 
life cycle inventory process subtracting the costs incurred in production of vanadium feedstock. Finally, an impact assessment is performed for different grades of steel utilizing vanadium consumption and steel production data to obtain realistic quantification of embodied energy and carbon benefits of microalloying on a global scale and for specific regions of the world.

\subsection{Data Sources}

The following sub-sections briefly discuss the data sources used to develop the LCA model.

\subsubsection{Structural modeling}

For structural modeling the parameters for analysis are taken from and conform to the following structural design standards:

(a) EN 1990: Structural design details;(EN 1990:2002+A1, 2005) (b) EN 1991-1-1: Dead and live load specifications for buildings;(EN 1991-1-1, 2002) (c) EN 1991-1-4: Wind load specifications;(EN 1991-1-4, 2010) (d) EN 1992-1-1: All analysis and design parameters for reinforced concrete structures;(EN 1992-1-1, 2004) (e) EN 1997-1: Geotechnical design details (foundation design);(EN 1997-1, 2004) (f) BS 4449:1997: Mild steel rebar grade details;(BS 4449:1997, 1997) (g) BS 4449:2005: High strength steel rebar grade details;(Steel for the Reinforcement of Concrete-Weldable Reinforcing Steel-Bar, Coil and Decoiled Product Specification, 2005) (h) EN 206-1: Concrete specifications;(EN 206-1, 2000) (i) EN 10080:2005 (E): Standard nominal bar sizes(British Standards Institute, 2005)

\subsubsection{Machine Learning Model of Yield Strength as a Function of Alloy Composition}

The literature reports a wide range of yield strengths as a function of different alloying elements with varying concentrations processed using different thermal transformation profiles 
(Deping et al., 2000; Lv et al., 2014; Milbourn et al., 2010; Sage, 1976; Shihuai et al., 2003; Yongquan et al., 1998). In order to arrive at aggregated data not specific to conditions of a single trial, yield strength dependences as a function of alloying element concentrations have been determined by considering the results of 67 different experiments mined from the literature by developing a statistical regression model (Deping et al., 2000; Lv et al., 2014; Sage, 1976; Shihuai et al., 2003).

\subsubsection{Life Cycle Inventory}

In order to perform life cycle assessment, the Inventory of Carbon and Energy (ICE v2.0) has primarily been used to evaluate the embodied energy and embodied carbon derived from steel and concrete (Hammond and Jones, 2011). ICE is an open access embodied energy and carbon emissions database that includes the cradle-to-site energy and carbon values associated with the construction industry. The embodied energy and carbon values of most construction materials may be found in this database. The embodied energy and carbon associated with extraction and coproduction of vanadium is derived from the literature (Synthesis, 2014; Weber et al., 2018). Specifically, the work of Eckelman and colleagues have estimated $33.1 \mathrm{~kg} \mathrm{CO}_{2} / \mathrm{kg} \mathrm{V}$ and 516 $\mathrm{MJ} / \mathrm{kg} \mathrm{V}$ for embodied carbon and energy, respectively (Synthesis, 2014). These results are consistent with calculations based on a recent life cycle analysis of a hypothetical vanadium redox flow battery $\left(39.1 \mathrm{~kg} \mathrm{CO}_{2} / \mathrm{kg} \mathrm{V}_{2} \mathrm{O}_{5}\right)$. Collectively, a combination of primary, secondary, and coproduction methods were considered.

\subsection{Design Methodology}

\subsubsection{Structural Modeling}

A structural modeling framework has been developed to calculate the quantities of steel and concrete required to achieve the same load-bearing capacity for different grades of 
reinforcement bars (corresponding to different vanadium concentrations). The structural codes used for this analysis are delineated in §2.1.1. Grade $250 \mathrm{MPa}$ ( $\sim 36 \mathrm{ksi})$ steel (mild steel) is taken as the baseline for evaluating savings in energy and carbon. Two distinct levels of structural modeling have been performed at the component and building level.

At the component level, individual structural components such as a reinforced concrete (RC) slab, RC beam, RC column and foundation are analyzed and the material quantities are calculated for different strengths of steel. All analysis and design parameters for reinforced components primarily conform to Eurocode 2 (EN 1992-1-1) (EN 1992-1-1, 2004). Figure 2 shows 3D renditions of (a) RC beam and (b) RC column analyzed in this exercise.

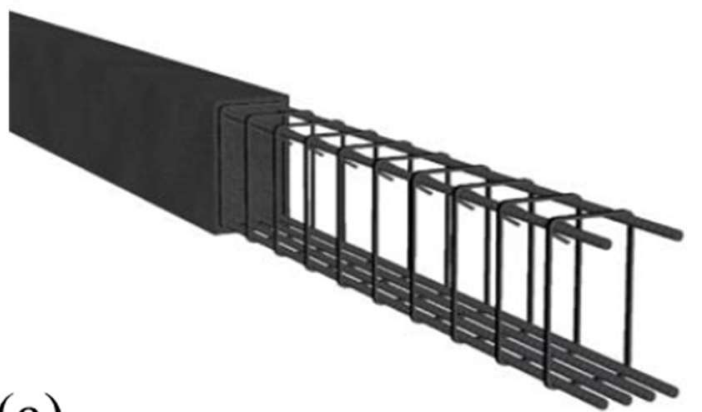

(a).

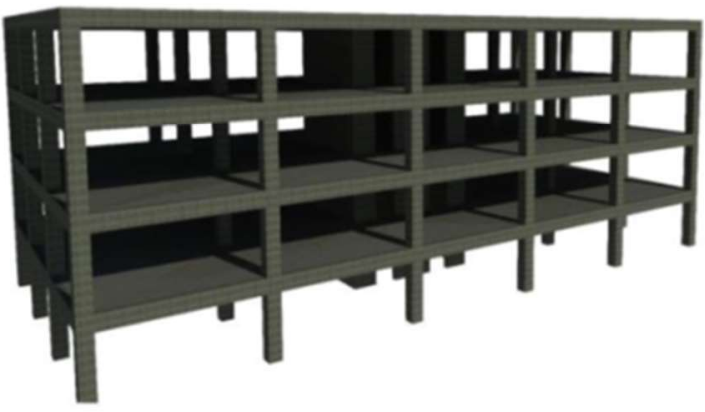

(c). (b).

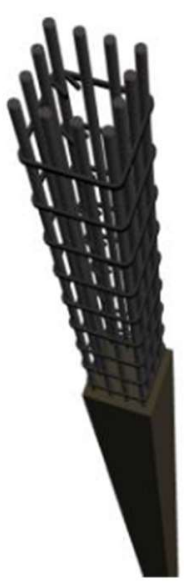

(d).

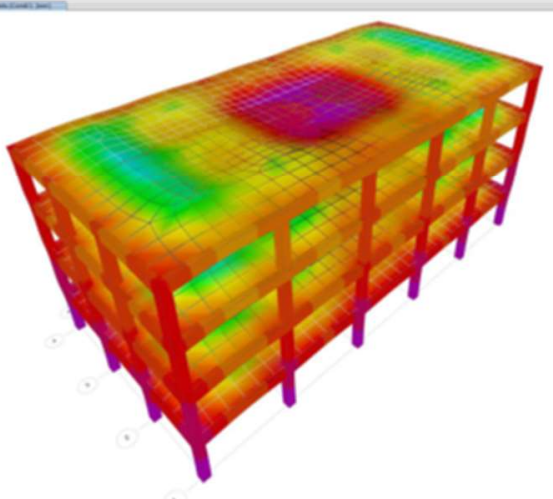


Figure 2: 3D renditions of structural components and hypothetical building model. (a). Reinforced concrete beam that illustrates the horizontal load bearing structural component with longitudinal and shear reinforcement to resist flexure and shear, respectively; (b). Reinforced concrete column that illustrates the vertical load bearing structural component with vertical reinforcing bars and stirrups to transfer the load from slabs and beams to the foundation; (c). Hypothetical building model developed using Revit that illustrates a typical reinforced concrete building, with RC slabs, RC beams and RC columns, which is subjected to standard loading and site conditions; and (d). ETABS model of the hypothetical building that illustrates the structural response after performing the structural analysis.

At the building level, a four-story $-5 \times 3$ bay hypothetical building has been modeled. Figure 2c shows a 3D rendition of the building model. Each story has a height of 4 meter; the bays span 7 m (5 bays) and 5.5 m (3 bays). Building Category C1 (schools, restaurants, etc - Table 6.1, EN 1991-1) (EN 1991-1-1, 2002) is used to develop the hypothetical building with roof type H (roof accessible only for maintenance and repair -as per Table 6.9, EN 1991-1) (EN 1991-1-1, 2002). The ETABS v18 structural software has been used to design and analyze the structure. Figure $2 \mathrm{~d}$ shows the analyzed hypothetical building model. Dead, live, and wind load values have been acquired from Eurocode 1991-1-1 (EN 1991-1-1, 2002) and 1991-1-4, (EN 1991-1-4, 2010) respectively. The total quantities of materials for structural beams and columns are derived from design results for different strengths of steel. Since, in the analysis, only superstructure is analyzed, approximately $70 \%$ of the total steel quantity within a building (beams, columns and slabs) is estimated to be in beams and columns. However, this value is dependent on the model- strength of steel, loading and geometric properties of structural components and it will be lower if the building foundation is further considered in the analysis. Eurocode 1992-1-1 (EN 1992-1-1, 2004) specifications are used to design RC sections in the ETABS software. 
For all models C30/37 MPa concrete (specifications taken from EN 206-1) (EN 206-1, 2000) is used in conjunction with Grade 400 (400 MPa), Grade 500 (500 MPa), and Grade 600 (600 MPa) reinforcement bars, corresponding to different extents of vanadium alloying. Grade 250 (250 $\mathrm{MPa}$ ) with no vanadium incorporation is used as the baseline to compare reduction in steel consumption accruing from vanadium incorporation. For foundation component design, the soilbearing capacity is assumed to be $200 \mathrm{kN} / \mathrm{m}^{2}$. The densities of steel and concrete are taken as 7850 and $2400 \mathrm{~kg} / \mathrm{m}^{3}$, respectively.

\subsubsection{Developing a Machine Learning Model to Predict the Yield Strength of V-HSLA Steels}

Given the multitude of variables that may affect yield strength in the steel, there exists considerable variability in the preparation of a reinforcement bar meeting certain structural specifications. For example, two identical grades of rebar might be prepared using distinct thermal conditions and chemical compositions. Nevertheless, efforts have been made to develop empirical models that predict the yield strength of a V-HSLA steels as a function of vanadium concentration. However, previous models have been limited to linear regression models (Glodowski, 2014). Here, we have instead developed a machine learning model based on support vector machine (SVM) analysis in order to provide a robust method to delineate vanadium-derived strengthening effects in HSLA steels. SVM is a widely used technique for data classification and regression analysis of multivariate data; the details and applications behind SVM been discussed in detail elsewhere (Braham et al., 2019; Suykens and Vandewalle, 1999). The e1071 R package version 1.6-8 was utilized to compute the support vector machine and regression (Meyer et al., 2017). SVM calculations were algorithmically tuned to pick the best performing cost and gamma terms for the radial basis function calculation using "leave-one-out" cross validation as a performance metric. 
A total of 67 steel trials varying by composition and yield strength were mined from peerreviewed publications to create a materials design space that considers (a) weight percent amounts of $\mathrm{C}, \mathrm{Si}, \mathrm{Mn}, \mathrm{V}$, and $\mathrm{N}$ in addition to (b) the bar diameter in order to correlate composition and yield strength (Deping et al., 2000; Lv et al., 2014; Sage, 1976; Shihuai et al., 2003). Prior to the SVM computation, all samples were subject to a set of metallurgical constraints in order to better curate the dataset and obtain an unambiguous evaluation of the effects of vanadium addition. First, the steels considered for the model are free of other commonly used microalloying elements which are competitive for the formation of carbonitrides in HSLA steels including, $\mathrm{Cu}, \mathrm{Nb}$, and $\mathrm{Ti}$. Secondly, the dataset was curated to include only "as-rolled" steels without any quench and selftempering processes, which are known to greatly modify the microstructure and thus the yield strength. Features were ranked on how well individual variables correlated to yield strength by calculating correlation coefficients for a linear regression of each independent variable individually as delineated in Table 1 .

Table 1: Features considered for the SVM model are ranked based on how individual variables are correlated to yield strength by calculating correlation coefficients for a linear regression of each independent variable individually 


\begin{tabular}{|l|r|}
\hline Variable & \multicolumn{1}{|l|}{} \\
\hline Vanadium content & 0.578 \\
\hline Manganese content & 0.224 \\
\hline Nitrogen Content & 0.224 \\
\hline Carbon content & 0.153 \\
\hline Phosphorus content & 0.073 \\
\hline Sulfur Content & 0.099 \\
\hline Silicon Content & 0.068 \\
\hline Oxygen Content & 0.047 \\
\hline Aluminum Content & 0.027 \\
\hline Bar Diameter & 0.025 \\
\hline
\end{tabular}

The model identifies nitrogen, vanadium, and manganese content as the three most statistically significant descriptors for the prediction of yield strength. Given that the primary mechanisms of strength addition stems from the formation of vanadium carbonitrides, it is not surprising that vanadium and nitrogen are amongst the top descriptors of yield strength. Similarly, manganese content is known to contribute to the steel strength by solid-solution strengthening (Garcia, 2016). The visualization in Figure 3 and Video S1 shows the model across the variables of vanadium, nitrogen, and manganese (temporal axis) weight percent while holding the carbon content constant at $0.22 \mathrm{wt} . \%$, silicon content at $0.4 \mathrm{wt} . \%$, and the bar diameter at $30 \mathrm{~mm}$. 


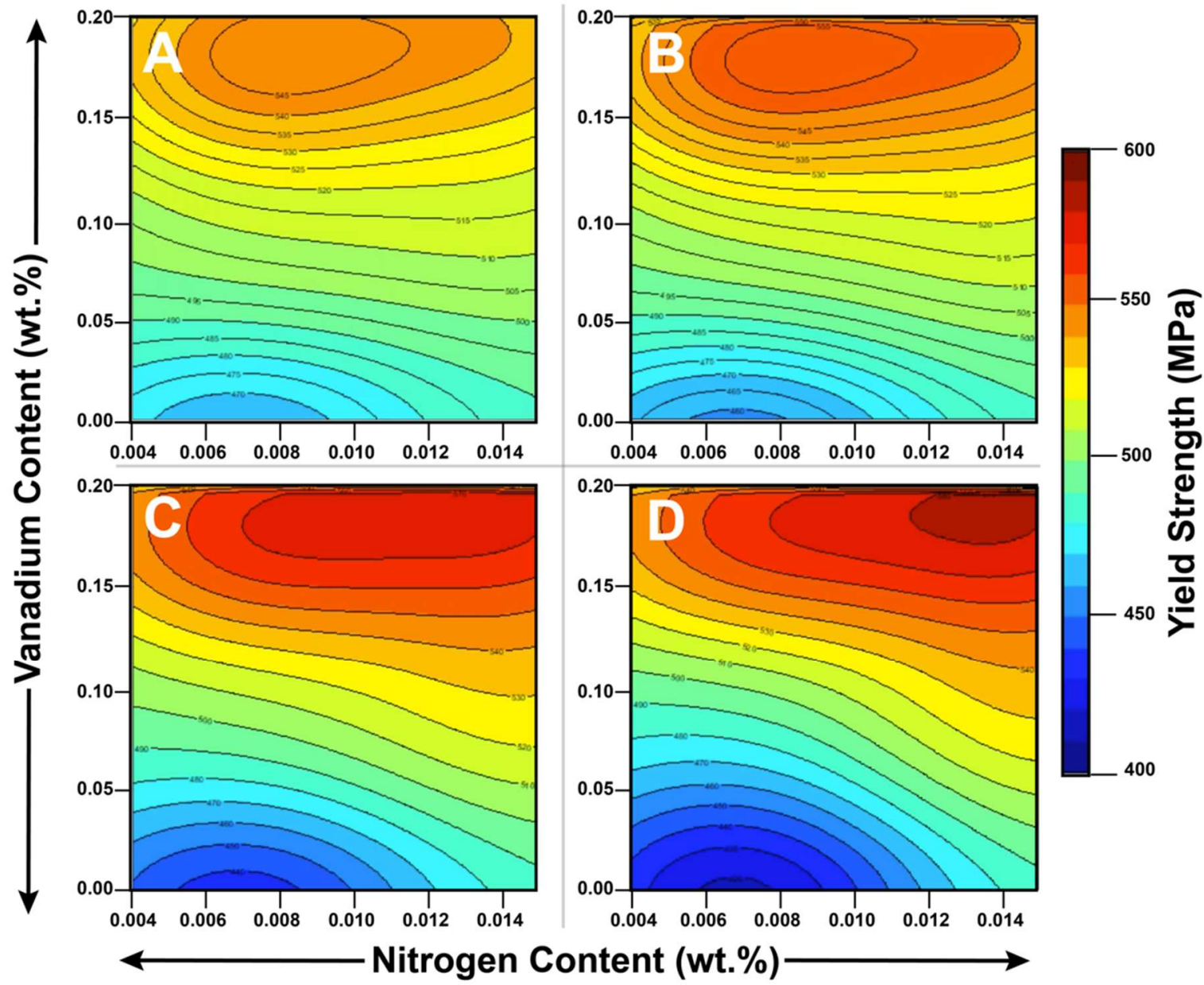

Figure 3: Contour plot slices of the SVM regression showing the intersections of nitrogen and vanadium content at various manganese amounts (a) 1.100; (b) 1.124; (c) 1.172; and (d) $1.244 \mathrm{Mn}$ wt.\%. Video S1 shows the continuous evolution of the contours as a function of manganese content.

For the LCA calculations, a base steel composition comprised of 0.220 carbon, 0.008 nitrogen, and 1.24 manganese by wt.\% was considered; vanadium weight percentages corresponding to 400,500, and $600 \mathrm{MPa}$ steels were calculated from the machine learning model, and are shown in Table 2. The SVM model provides yield-strength-vanadium content ratios that are indeed concordant with previous literature results (Bushveld, 2018; Skobir, 2011).

Table 2. Chemical composition corresponding to 400, 500, and $600 \mathrm{MPa}$ steel calculated from the SVM model by fixing carbon, manganese, and nitrogen content allowing for variable vanadium content 


\begin{tabular}{|c|c|c|c|c|c|}
\hline de Gra & $\begin{array}{l}\quad \text { Yie } \\
\text { ld } \\
\text { Strength } \\
\text { (MPa) }\end{array}$ & $\begin{array}{l}\text { Carb } \\
\text { on (wt.\%) }\end{array}$ & $\begin{array}{l}\text { Mangan } \\
\text { ese (wt.\%) }\end{array}$ & $\begin{array}{r}\text { Nitro } \\
\text { gen (wt. } \%)\end{array}$ & $\begin{array}{l}\text { Vanadi } \\
\text { um (wt.\%) }\end{array}$ \\
\hline 400 & $\begin{array}{ll} & 40 \\
0 & \end{array}$ & 0.220 & 1.24 & 0.008 & 0.013 \\
\hline 500 & 50 & 0.220 & 1.24 & 0.008 & 0.095 \\
\hline 600 & $\begin{array}{ll} & 60 \\
0 & \end{array}$ & 0.220 & 1.24 & 0.008 & 0.177 \\
\hline
\end{tabular}

\subsubsection{Life-Cycle Assessment}

As noted above, LCA is a tool to evaluate the cradle-to-grave environmental effects of an activity. Life-cycle assessment primarily deals with inventory analysis and impact assessment, and in some cases provides insight into avenues for process improvements. In this study, the goal is to develop a global view of the potential energy and carbon benefits of vanadium use in rebar steel and to then parse these benefits across different geographic regions. The Inventory of Carbon and Energy (ICE) database is robust and well documented and has been used as the primary framework for our calculations. The embodied environmental impacts of production encompass both direct and indirect components. The direct component represents the energy use and carbon emission of a plant manufacturing reinforcement bars, whereas the energy and carbon impacts of raw material used for rebar production constitute indirect impacts. Databases derived from hybrid LCA methods yield excellent coverage of the direct and indirect impacts of common construction materials and processes. Table 3 lists energy and carbon values for reinforcement bar steel and concrete extracted from ICE v2.0 and carried forward in our LCA calculations.

Table 3: Carbon and energy data for steel rebar, concrete and vanadium where the values for steel rebar extracted from ICE v2.0 for UK typical with EU 27 3-year average recycled content of 59\% in steel production 


\begin{tabular}{|c|c|c|}
\hline & $\begin{array}{c}\text { Embodied } \\
\text { Energy } \\
\text { (MJ/ kg) }\end{array}$ & $\begin{array}{c}\text { Embodied } \\
\text { Carbon } \\
(\mathrm{kg} \mathrm{CO} 2 \mathrm{e} / \mathrm{kg})\end{array}$ \\
\hline Rebar & $\begin{array}{l}17.4 \text { (Hammond } \\
\text { and Jones, 2011) }\end{array}$ & $\begin{array}{c}1.4 \text { (Hammond and } \\
\text { Jones, 2011) }\end{array}$ \\
\hline $\begin{array}{l}\text { Concrete } \\
(\mathbf{3 0 / 3 7} \mathbf{M P a})\end{array}$ & $\begin{array}{l}0.85 \text { (Hammond } \\
\text { and Jones, 2011) }\end{array}$ & $\begin{array}{l}0.126 \text { (Hammond } \\
\text { and Jones, 2011) }\end{array}$ \\
\hline Vanadium & $\begin{array}{c}516 \text { (Synthesis, } \\
\text { 2014) }\end{array}$ & $\begin{array}{l}33.1 \text { (Synthesis, } \\
\text { 2014) - } \\
\text { 39.1(Weber et al., } \\
\text { 2018) }\end{array}$ \\
\hline
\end{tabular}

Embodied energy and carbon values for vanadium production were taken from literature and are listed in Table 3 (Synthesis, 2014; Weber et al., 2018).

The impact assessment includes the environmental impact in terms of embodied energy and $\mathrm{CO}_{2}$ emissions scaled using market data of global production supplied by Vanitec (Vanitec.org). The embodied energy of the different types of rebar is computed in primary energy units (MJ), which represents the specific heat value. The embodied carbon due to different types of rebar is computed in $\mathrm{kgs}$ of $\mathrm{CO}_{2}$ emission. The reduction in steel consumption derived from employing higher grades of reinforcement bars constituted from vanadium HSLA steels in comparison to baseline mild steel is translated to carbon and embodied energy metrics using the numbers in Table 3. The carbon and energy expenditure for production of vanadium is further determined and represents a debit to the energy and carbon benefits accrued from reduced steel consumption. The net results are scaled using global and regional market size and production data to determine the overall impact of vanadium microalloying in terms of energy and carbon savings. 


\section{Results}

\subsection{Quantification of the Embodied Energy and Carbon Impact of Reduction in Steel Consumption Derived from Structural Modeling}

Structural analyses of RC structural components have been performed and the results are combined with machine learning models and an LCA inventory analysis to produce the embodied energy and carbon savings associated with each model. Table 4(a) delineates the energy and carbon savings for RC slab, beam and column, whereas Table 4(b) shows the results of analogous calculations for RC footing. An increase in energy and carbon savings with increasing strength of steel is observed for all structural components. Note that reduction in the amount of steel typically necessitates increased consumption of concrete; however, the relatively higher embodied energy and carbon associated with steel production (Table 3) implies an overall savings in both energy and carbon even after accounting for the increased amount of concrete that is needed.

Table 4: Results of energy and carbon savings for RC slab, beam, column, footing comparing V HSLA rebar grades to mild steel. EE: embodied energy; EC: embodied carbon (Yield strength shown in bold denotes mild steel bar as the baseline)

\begin{tabular}{|c|c|c|c|c|c|c|}
\hline (a) & \multicolumn{2}{|c|}{ RC Slab } & \multicolumn{2}{|c|}{ RC Beam } & \multicolumn{2}{|c|}{ RC Column } \\
\hline \multirow{2}{*}{$\begin{array}{l}\text { Yield } \\
\text { Strength } \\
\text { (MPa) }\end{array}$} & \multicolumn{2}{|c|}{$\%$ Savings } & \multicolumn{2}{|c|}{$\%$ Savings } & \multicolumn{2}{|c|}{ \% Savings } \\
\hline & $\mathbf{E E}$ & $C^{E}$ & EE & EC & $\mathbf{E E}$ & $C^{\mathbf{E}}$ \\
\hline 250 & $0 \%$ & $0 \%$ & $\%$ & $\%^{0.00}$ & $0 \%$ & $0 \%{ }^{0.0}$ \\
\hline 400 & $1 \%{ }^{0.8}$ & $4 \%{ }^{0.4}$ & $6 \%$ & $2 \%$ & $2 \%$ & $9 \%$ \\
\hline 500 & $6 \%$ & $7 \%$ & $0 \%$ & $7 \%$ & $7 \%{ }^{6.6}$ & $6 \%$ \\
\hline 600 & $2 \%{ }^{1.2}$ & $7 \%$ & $8 \%$ & $0 \%$ & $3 \%{ }^{8.8}$ & $2 \%{ }^{9.7}$ \\
\hline
\end{tabular}




\begin{tabular}{|r|c|c|}
\hline \multirow{2}{*}{ (b) } & \multicolumn{2}{|c|}{ RC Footing } \\
\hline $\begin{array}{c}\text { Yield } \\
\text { Strength } \\
\text { (MPa) }\end{array}$ & \multicolumn{2}{|c|}{ \% Savings } \\
\cline { 2 - 3 } & EE & EC \\
\hline $\mathbf{2 5 0}$ & $0.00 \%$ & $0.00 \%$ \\
\hline 500 & $12.09 \%$ & $7.37 \%$ \\
\hline
\end{tabular}

The component level models have further been extrapolated to calculate the energy and carbon savings from a hypothetical reinforced concrete building, which has been modeled using the ETABS v18 structural software as described in §2.2.1. Table 5 shows the projected energy and carbon savings for the hypothetical building for different grades of vanadium microalloyed steel in comparison to a $250 \mathrm{MPa}$ mild steel baseline.

Table 5: Results of energy and carbon savings for the hypothetical RC building depicted in Figure 2 (c, d) as calculated using the ETABS software (Yield strength shown in bold denotes mild steel bar as baseline)

\begin{tabular}{|c|c|c|}
\hline \multirow{2}{*}{$\begin{array}{c}\text { Yield } \\
\text { Strength } \\
\text { (MPa) }\end{array}$} & \multicolumn{2}{|c|}{$\%$ Savings } \\
\cline { 2 - 3 } & $\mathbf{E E}$ & EC \\
\hline $\mathbf{2 5 0}$ & $0.00 \%$ & $0.00 \%$ \\
\hline 400 & $17.33 \%$ & $12.26 \%$ \\
\hline 500 & $22.65 \%$ & $16.16 \%$ \\
\hline 600 & $26.26 \%$ & $18.83 \%$ \\
\hline
\end{tabular}

\subsection{Extrapolation of Embodied Energy and Carbon Savings to Regional and Global Impact}

Some of the most granular data on vanadium consumption in steel for reinforcement bar applications comes from China, which has seen a large upheaval of the construction industry as a result of federally mandated rebar standards ("China's inspections to speed up rebar standards rollout," 2019) introduced in 2018. The elimination of rebar grade HRB335 and establishment of 
a new HRB600 grade to enhance the resilience of buildings to earthquakes, spurred in large measure by the devastation wrought by the 2008 Sichuan earthquake, has prompted a significant increase in vanadium consumption (Patel, 2018; "Vanadium: New Chinese rebar standards positive for ferrovanadium demand," 2018). Grade 3 (400MPa), Grade 4 (500MPa), and Grade 5 $(600 \mathrm{MPa})$ reinforcement bars manufactured in China are estimated to require $0.03 \%, 0.06 \%$, and more than $0.1 \% \mathrm{~V}$, respectively, which is generally consistent with expectations from the machine learning model in Figure 3 and Table 2.

In 2018, the total amount of vanadium consumed in rebar applications in China was 29,000 metric tons (MT) (Bushveld, 2018) of which 20,300 MT is assumed to be used in beams and columns. Table 6 extrapolates these numbers to two scenarios accounting for the entire vanadium consumption being utilized in either $400 \mathrm{MPa}$ or $600 \mathrm{MPa}$ rebar based on vanadium content required to achieve these yield strengths derived from the machine learning model in Figure 3. Considering Table 6 , if all 20,300 MT of vanadium is considered to have gone into the manufacture of $400 \mathrm{MPa}$ rebar, this accounts for 156,153,846 MT of rebar with vanadium microalloying. Based on the structural modeling results delineated in Table 5, the above mentioned quantity of rebar translates to an $81 \mathrm{mMT}$ reduction of steel consumption in comparison to $250 \mathrm{MPa}$ steel having the same loading and geometric parameters. The steel savings can be directly translated to embodied energy and carbon savings after debiting the costs of vanadium incorporation (from Table 2); embodied energy savings of $1,399 \times 10^{9}$ Mega Joules (MJ) and $\mathrm{CO}_{2}$ savings of 0.1127 Giga tons (Gt) $\mathrm{CO}_{2}$ emissions can be thus directly attributed to supplanting $250 \mathrm{MPa}$ rebar with $400 \mathrm{MPa}$ rebar. Using China's total fossil fuel-related carbon emission figures as 9.8 Gt, (Global Carbon Budget, 2018) this equates to a $1.15 \%$ reduction in the carbon footprint as a result of reduced steel consumption directly attributable to microalloying. The lower half of Table 6 
represents corresponding numbers if all of the vanadium was used for production of $600 \mathrm{MPa}$ and sets a lower bound for savings in embodied energy and carbon at $0.18 \%$.

Table 6: Energy and carbon savings using vanadium in rebar market data (China) and assuming vanadium amounts quantified using the machine learning model. The steel column denotes the total steel consumption. The EE and EC columns denote the net savings in embodied energy and carbon for 400 and $600 \mathrm{MPa}$ rebar. (Yield strength shown in bold denotes mild steel bar as baseline)

\begin{tabular}{|c|c|c|c|c|c|c|c|c|}
\hline \multirow{2}{*}{$\begin{array}{c}\text { Yield } \\
\text { Strength } \\
\text { (MPa) }\end{array}$} & \multirow[b]{2}{*}{ Steel $(t)$} & \multirow{2}{*}{$\begin{array}{l}\text { Vanadium } \\
\text { (t) }\end{array}$} & \multirow{2}{*}{$\begin{array}{c}\text { EE } \\
(\mathbf{x 1 0})^{9} \\
\text { MJ) } \\
\end{array}$} & \multirow{2}{*}{$\begin{array}{c}\mathbf{E C} \\
\mathbf{G t} \\
\left.\mathrm{CO}_{2} \mathbf{e}\right) \\
\end{array}$} & \multicolumn{2}{|c|}{ Savings } & \multicolumn{2}{|c|}{$\begin{array}{c}\text { China Carbon } \\
\text { Savings }\end{array}$} \\
\hline & & & & & EE & EC & $\begin{array}{c}(\mathrm{Gt} \\
\left.\mathrm{CO}_{2} \mathrm{e}\right)\end{array}$ & $\%$ \\
\hline 250 & $237,160,414$ & 0 & 4,127 & 0.3320 & $0.00 \%$ & $0.00 \%$ & 0.000 & $0.00 \%$ \\
\hline 400 & $156,153,846$ & 20,300 & 2,728 & 0.2193 & $33.90 \%$ & $33.95 \%$ & 0.113 & $1.15 \%$ \\
\hline \multirow{2}{*}{$\begin{array}{l}\text { Yield } \\
\text { Strength } \\
\text { (MPa) }\end{array}$} & \multirow{2}{*}{ Steel (t) } & \multirow{2}{*}{$\begin{array}{l}\text { Vanadium } \\
\text { (t) }\end{array}$} & EE & EC & \multicolumn{2}{|c|}{ Savings } & \multicolumn{2}{|c|}{$\begin{array}{c}\text { China Carbon } \\
\text { Savings }\end{array}$} \\
\hline & & & $\begin{array}{r}(\mathbf{x 1 0})^{9} \\
\text { MJ) }\end{array}$ & $\begin{array}{c}(\mathbf{G t} \\
\left.\mathrm{CO}_{2} \mathrm{e}\right) \\
\end{array}$ & $\mathbf{E E}$ & EC & $\begin{array}{c}(\mathbf{G t} \\
\left.\mathrm{CO}_{2} \mathbf{e}\right) \\
\end{array}$ & $\%$ \\
\hline 250 & $24,668,709$ & 0 & 429 & 0.0345 & $0.00 \%$ & $0.00 \%$ & 0.000 & $0.00 \%$ \\
\hline 600 & $11,468,927$ & 20,300 & 210 & 0.0167 & $51.07 \%$ & $51.56 \%$ & 0.018 & $0.18 \%$ \\
\hline
\end{tabular}

A more detailed assessment of the market data segmented by rebar grade allows for further refinement of the embodied carbon and steel numbers. In 2017, $130 \mathrm{mMT}$ of $400 \mathrm{MPa}$ reinforcement bars were produced in China, whereas the production of $500 \mathrm{MPa}$ and $600 \mathrm{MPa}$ reinforcement bars were $40 \mathrm{mMT}$ and $0.9 \mathrm{mMT}$, respectively (Bushveld, 2018). Extrapolating these numbers to steel used in beams and columns and based on vanadium consumption data, 9,800 MT of vanadium was used for production of $400 \mathrm{MPa}$ and $500 \mathrm{MPa}$ rebars, and $700 \mathrm{MT}$ for production of $600 \mathrm{MPa}$ rebar. Table 7 delineates the embodied energy and carbon savings with these quantities of rebar. Summing the savings from each grade of rebar allows us to arrive at a more granular estimate of $1.01 \%$ reduction in the total fossil carbon footprint of China because of reduced steel consumption directly attributable to microalloying in 2017. 
Table 7: Energy and carbon savings using vanadium in rebar market data (China) and taking vanadium and steel amounts for each grade of steel from available China rebar break up. The steel column denotes the total steel consumption. The EE and EC columns denote the net savings in embodied energy and carbon for 400, 500, and $600 \mathrm{MPa}$ rebar. (Yield strength shown in bold denotes mild steel bar as the baseline)

\begin{tabular}{|c|c|c|c|c|c|c|c|c|}
\hline \multirow{2}{*}{$\begin{array}{c}\text { Yield } \\
\text { Strength } \\
\text { (MPa) }\end{array}$} & \multirow{2}{*}{ Steel (t) } & \multirow{2}{*}{$\begin{array}{c}\text { Vanadium } \\
\text { (t) }\end{array}$} & \multirow{2}{*}{$\begin{array}{c}\text { EE } \\
\left(\mathbf{x 1 0}{ }^{9}\right. \\
\text { MJ) }\end{array}$} & \multirow{2}{*}{$\begin{array}{c}\text { EC } \\
(\mathrm{Gt} \\
\left.\mathrm{CO}_{2} \mathrm{e}\right)\end{array}$} & \multicolumn{2}{|c|}{ Savings } & \multicolumn{2}{|c|}{$\begin{array}{c}\text { China Carbon } \\
\text { Savings }\end{array}$} \\
\hline & & & & & $\mathbf{E E}$ & EC & $\begin{array}{c}(\mathrm{Gt} \\
\left.\mathrm{CO}_{2} \mathrm{e}\right)\end{array}$ & $\%$ \\
\hline 250 & $138,207,275$ & 0 & 2,405 & 0.1935 & $0.00 \%$ & $0.00 \%$ & 0.000 & $0.00 \%$ \\
\hline 400 & $91,000,000$ & 9,800 & 1,588 & 0.1277 & $33.95 \%$ & $33.99 \%$ & 0.066 & $0.67 \%$ \\
\hline \multirow{2}{*}{$\begin{array}{c}\text { Yield } \\
\text { Strength } \\
\text { (MPa) }\end{array}$} & \multirow{2}{*}{ Steel (t) } & \multirow{2}{*}{$\begin{array}{c}\text { Vanadium } \\
\text { (t) }\end{array}$} & $\mathbf{E E}$ & EC & \multicolumn{2}{|c|}{ Savings } & \multicolumn{2}{|c|}{$\begin{array}{c}\text { China Carbon } \\
\text { Savings }\end{array}$} \\
\hline & & & $\begin{array}{l}(\mathbf{x 1 0} \\
\text { MJ) }\end{array}$ & $\begin{array}{c}(\mathrm{Gt} \\
\left.\mathrm{CO}_{2} \mathrm{e}\right)\end{array}$ & $\mathbf{E E}$ & EC & $\begin{array}{c}(\mathbf{G t} \\
\left.\mathrm{CO}_{2} \mathrm{e}\right)\end{array}$ & $\%$ \\
\hline 250 & $51,570,772$ & 0 & 897 & 0.0722 & $0.00 \%$ & $0.00 \%$ & 0.000 & $0.00 \%$ \\
\hline 500 & $28,000,000$ & 9,800 & 492 & 0.0395 & $45.14 \%$ & $45.26 \%$ & 0.033 & $0.33 \%$ \\
\hline \multirow{2}{*}{$\begin{array}{c}\text { Yield } \\
\text { Strength } \\
\text { (MPa) }\end{array}$} & \multirow{2}{*}{ Steel (t) } & \multirow{2}{*}{$\begin{array}{c}\text { Vanadium } \\
\text { (t) }\end{array}$} & $\mathbf{E E}$ & EC & \multicolumn{2}{|c|}{ Savings } & \multicolumn{2}{|c|}{$\begin{array}{c}\text { China Carbon } \\
\text { Savings }\end{array}$} \\
\hline & & & $\begin{array}{l}\left(\mathbf{x} 10^{9}\right. \\
\text { MJ) }\end{array}$ & $\begin{array}{c}(\mathrm{Gt} \\
\left.\mathrm{CO}_{2} \mathrm{e}\right)\end{array}$ & $\mathbf{E E}$ & EC & $\begin{array}{c}(\mathbf{G t} \\
\left.\mathrm{CO}_{2} \mathrm{e}\right) \\
\end{array}$ & $\%$ \\
\hline 250 & $1,355,078$ & 0 & 24 & 0.0019 & $0.00 \%$ & $0.00 \%$ & 0.000 & $0.00 \%$ \\
\hline 600 & 630,000 & 700 & 11 & 0.0009 & $51.98 \%$ & $52.29 \%$ & 0.001 & $0.01 \%$ \\
\hline \multicolumn{9}{|c|}{ Total $\mathbf{1 . 0 1 \%}$ savings in China's Carbon emissions } \\
\hline
\end{tabular}

The European Union (EU) has a vastly different construction industry that relies more extensively on tempering treatments. Vanadium consumption in the EU in 2017 was 12,700 MT but only $30 \%$ of the vanadium goes towards reinforcement bar applications, (Bushveld, 2018; “Data provided by VANITEC Market Development Committee," 2019) representing a total of 3,810 MT (of which 2,667 MT are used for RC beams and columns). Assuming this entire amount goes towards the production of $400 \mathrm{MPa}$ reinforcement bars yields $20.5 \mathrm{mMT}$ of steel, which represents steel savings of $10.6 \mathrm{mMT}$ over baseline $250 \mathrm{MPa}$ reinforcement bars (Table 8). Based on the embodied energy and carbon values delineated in \$2.2.3, the utilization of $400 \mathrm{MPa}$ reinforcement bars brings about a cumulative embodied energy savings of $184 \times 10^{9} \mathrm{MJ}$ and 
embodied carbon savings of $0.015 \mathrm{Gt} \mathrm{CO}_{2}$. A similar analysis is presented with the assumption that the entire vanadium amount of 2,667 MT goes towards production of $600 \mathrm{MPa}$ reinforcement bars in the lower half of Table 8 to establish a lower bound. Fossil carbon emissions in the EU totaled 3.5 Gt (Global Carbon Budget, 2018) in 2017; Table 8 suggests a $0.07-0.42 \%$ reduction in the carbon footprint of the EU as a result of reduced steel consumption directly attributable to microalloying in 2018. More granular analysis necessitates segmented market size information on different grades of V HSLA rebar.

Table 8: Energy and carbon savings using vanadium in rebar market data (EU) and assuming vanadium amounts quantified using the machine learning model. The steel column denotes the total steel consumption. The EE and EC columns denote the net savings in embodied energy and carbon for 400 and $600 \mathrm{MPa}$ rebar. (Yield strength shown in bold denotes mild steel bar as the baseline)

\begin{tabular}{|c|c|c|c|c|c|c|c|c|}
\hline \multirow{2}{*}{$\begin{array}{c}\text { Yield } \\
\text { Strength } \\
\text { (MPa) }\end{array}$} & \multirow{2}{*}{ Steel $(t)$} & \multirow{2}{*}{$\begin{array}{l}\text { Vanadium } \\
\text { (t) }\end{array}$} & \multirow{2}{*}{$\begin{array}{c}\text { EE } \\
(\mathbf{x 1 0})^{9} \\
\text { MJ) }\end{array}$} & \multirow{2}{*}{$\begin{array}{c}\mathbf{E C} \\
(\mathbf{G t} \\
\left.\mathrm{CO}_{2} \mathbf{e}\right)\end{array}$} & \multicolumn{2}{|c|}{ Savings } & \multicolumn{2}{|c|}{$\begin{array}{c}\text { EU Carbon } \\
\text { Savings }\end{array}$} \\
\hline & & & & & EE & EC & $\begin{array}{c}(\mathrm{Gt} \\
\left.\mathrm{CO}_{2} \mathrm{e}\right)\end{array}$ & $\%$ \\
\hline 250 & $31,157,972$ & 0 & 542 & 0.0436 & $0.00 \%$ & $0.00 \%$ & 0.000 & $0.00 \%$ \\
\hline 400 & $20,515,385$ & 2,667 & 358 & 0.0288 & $33.90 \%$ & $33.95 \%$ & 0.015 & $0.42 \%$ \\
\hline \multirow{2}{*}{$\begin{array}{l}\text { Yield } \\
\text { Strength } \\
\text { (MPa) }\end{array}$} & \multirow{2}{*}{ Steel (t) } & \multirow{2}{*}{$\begin{array}{l}\text { Vanadium } \\
\text { (t) }\end{array}$} & $\mathbf{E E}$ & EC & \multicolumn{2}{|c|}{ Savings } & \multicolumn{2}{|c|}{$\begin{array}{c}\text { EU Carbon } \\
\text { Savings }\end{array}$} \\
\hline & & & $\begin{array}{l}\left(\mathbf{x 1 0}{ }^{9}\right. \\
\text { MJ) }\end{array}$ & $\begin{array}{c}(\mathbf{G t} \\
\left.\mathrm{CO}_{2} \mathrm{e}\right)\end{array}$ & EE & EC & $\begin{array}{c}(\mathrm{Gt} \\
\left.\mathrm{CO}_{2} \mathrm{e}\right)\end{array}$ & $\%$ \\
\hline 250 & $3,240,958$ & 0 & 56 & 0.0045 & $0.00 \%$ & $0.00 \%$ & 0.000 & $0.00 \%$ \\
\hline 600 & $1,506,780$ & 2,667 & 28 & 0.0022 & $51.07 \%$ & $51.56 \%$ & 0.002 & $0.07 \%$ \\
\hline
\end{tabular}

One approach to developing a more granular analysis is based on a dataset that indicates that the 2016 production of reinforcement bars in the EU was 11 mMT; (World Steel Associaiton, 2018 ) assuming that ca. $70 \%$ of this goes towards beams and columns, this yields a number of 7.7 mMT of steel, which incorporates 2,667 MT of vanadium in total ("Data provided by VANITEC Market Development Committee," 2019). Assuming a simplified two-grade system using total 
steel (7.7 mMT) and vanadium (2,667 MT) quantities and steel-vanadium relationship using machine learning model results (Table 2), 33\% of consumed vanadium or ca. 869 MT goes into $400 \mathrm{MPa}$ steel and $67 \%$ or ca. $1,798 \mathrm{MT}$ goes into $600 \mathrm{MPa}$ steel, while $87 \%$ or ca. $6.7 \mathrm{mMT}$ of steel goes into $400 \mathrm{MPa}$ and $13 \%$ or ca. $1 \mathrm{mMT}$ steel into $600 \mathrm{MPa}$. Table 9 plots the proportionately scaled embodied energy and carbon savings, which translates to a cumulative $0.19 \%$ reduction in the total fossil fuel-related carbon footprint of the EU as a result of reduced steel consumption directly attributable to microalloying.

Table 9: Energy and carbon savings using vanadium in rebar market data (EU) and vanadium amounts weighted by proportion of steel. The steel column denotes the total steel consumption. The EE and EC columns denote the net savings in embodied energy and carbon for 400 and 600 MPa rebar. (Yield strength shown in bold denotes mild steel bar as the baseline)

\begin{tabular}{|c|c|c|c|c|c|c|c|c|}
\hline \multirow{2}{*}{$\begin{array}{l}\text { Yield } \\
\text { Strength } \\
\text { (MPa) }\end{array}$} & \multirow{2}{*}{ Steel (t) } & \multirow{2}{*}{$\begin{array}{l}\text { Vanadium } \\
\text { (t) }\end{array}$} & \multirow{2}{*}{$\begin{array}{c}\text { EE } \\
\left(\mathbf{x 1 0 ^ { 9 }}\right. \\
\text { MJ) }\end{array}$} & \multirow{2}{*}{$\begin{array}{c}\mathrm{EC} \\
\left.\begin{array}{c}(\mathrm{Gt} \\
\left.\mathrm{CO}_{2} \mathrm{e}\right)\end{array}\right)\end{array}$} & \multicolumn{2}{|c|}{ Savings } & \multicolumn{2}{|c|}{$\begin{array}{c}\text { EU Carbon } \\
\text { Savings }\end{array}$} \\
\hline & & & & & $\mathbf{E E}$ & EC & $\begin{array}{c}(\mathrm{Gt} \\
\left.\mathrm{CO}_{2} \mathrm{e}\right)\end{array}$ & $\%$ \\
\hline 250 & $10,151,623$ & 0 & 177 & 0.0142 & $0.00 \%$ & $0.00 \%$ & 0.000 & $0.00 \%$ \\
\hline 400 & $6,684,146$ & 869 & 117 & 0.0094 & $33.90 \%$ & $33.95 \%$ & 0.005 & $0.14 \%$ \\
\hline & & & & & & & & \\
\hline \multirow{2}{*}{$\begin{array}{l}\text { Yield } \\
\text { Strength } \\
\text { (MPa) }\end{array}$} & \multirow{2}{*}{ Steel (t) } & \multirow{2}{*}{$\begin{array}{l}\text { Vanadium } \\
\text { (t) }\end{array}$} & $\mathbf{E E}$ & EC & \multicolumn{2}{|c|}{ Savings } & \multicolumn{2}{|c|}{$\begin{array}{c}\text { EU Carbon } \\
\text { Savings }\end{array}$} \\
\hline & & & $\begin{array}{l}\left(\mathbf{x 1 0}{ }^{9}\right. \\
\text { MJJ) }\end{array}$ & $\begin{array}{c}(\mathbf{G t} \\
\left.\mathrm{CO}_{2} \mathrm{e}\right)\end{array}$ & $\mathbf{E E}$ & EC & $\begin{array}{c}(\mathbf{G t} \\
\left.\mathrm{CO}_{2} \mathrm{e}\right)\end{array}$ & $\%$ \\
\hline 250 & $2,185,017$ & 0 & 38 & 0.0031 & $0.00 \%$ & $0.00 \%$ & 0.000 & $0.00 \%$ \\
\hline 600 & $1,015,854$ & 1,798 & 19 & 0.0015 & $51.07 \%$ & $51.56 \%$ & 0.0016 & $0.05 \%$ \\
\hline
\end{tabular}

We next turn our attention to developing a global perspective. In 2017, World Steel Association estimates that $235 \mathrm{mMT}$ of steel was used globally for reinforcement bars (Bushveld, 2018; World Steel Associaiton, 2018). An estimated 164 mMT was used for beams and columns.

One approach to calculate the energy and carbon savings is by extrapolating from China data that represents an upper bound of vanadium use in rebar, yields a total global utilization of vanadium in beams and columns as 43,720 MT. A rebar break-up similar to the one provided in the China 
data is used to extrapolate the steel rebar quantities the goes into each grade of steel. Table 10 shows the associated embodied energy and carbon savings. Considering global $\mathrm{CO}_{2}$ emissions of 36.2 Gt in 2017, this analysis yields an upper bound for reduction in total global fossil carbon footprint of $0.377 \%$ as a result of reduced steel consumption directly attributable to microalloying (Levin, 2018). These savings equate to the those gained, annually, by planting approximately two hundred sixty million trees (U.S. Forest Service, 2020).

Another approach is by extrapolating from EU data that represents a lower bound of vanadium intensity of use in rebar, yields a total global utilization of vanadium in beams and columns as 19,945 MT. Steel rebar quantities are extrapolated similar to EU steel break-up for each grade of steel. Table 11 shows the associated embodied energy and carbon savings. The analysis yields a lower bound for reduction in total global fossil carbon footprint of $0.385 \%$ as a result of reduced steel consumption directly attributable to microalloying (Levin, 2018).

Table 10: Energy and carbon savings using vanadium in rebar market data (Global) and vanadium amounts weighted by proportion of total steel for each grade. The steel column denotes the total steel consumption. Both vanadium and steel interpolated using China data. The EE and EC columns denote the net savings in embodied energy and carbon for 400, 500 and $600 \mathrm{MPa}$ rebar. (Yield strength shown in bold denotes mild steel bar as the baseline) 


\begin{tabular}{|c|c|c|c|c|c|c|c|c|}
\hline \multirow{2}{*}{$\begin{array}{c}\text { Yield } \\
\text { Strength } \\
\text { (MPa) }\end{array}$} & \multirow{2}{*}{ Steel $(t)$} & \multirow{2}{*}{$\begin{array}{l}\text { Vanadium } \\
\text { (t) }\end{array}$} & \multirow{2}{*}{$\begin{array}{c}\text { EE } \\
\left(\mathbf{x 1 0}{ }^{9}\right. \\
\text { MJ) }\end{array}$} & \multirow{2}{*}{$\begin{array}{c}\mathbf{E C} \\
(\mathbf{G t} \\
\left.\mathrm{CO}_{2} \mathbf{e}\right)\end{array}$} & \multicolumn{2}{|c|}{ Savings } & \multicolumn{2}{|c|}{$\begin{array}{c}\text { Global Carbon } \\
\text { Savings }\end{array}$} \\
\hline & & & & & EE & EC & $\begin{array}{l}(\mathrm{Gt} \\
\left.\mathrm{CO}_{2} \mathrm{e}\right) \\
\end{array}$ & $\%$ \\
\hline 250 & $189,853,450$ & 0 & 3,303 & 0.2658 & $0.00 \%$ & $0.00 \%$ & 0.000 & $0.00 \%$ \\
\hline 400 & $125,005,459$ & 21,106 & 2,186 & 0.1757 & $33.83 \%$ & $33.89 \%$ & 0.090 & $0.25 \%$ \\
\hline \multirow{2}{*}{$\begin{array}{c}\text { Yield } \\
\text { Strength } \\
\text { (MPa) }\end{array}$} & \multirow{2}{*}{ Steel (t) } & \multirow{2}{*}{$\begin{array}{l}\text { Vanadium } \\
\text { (t) }\end{array}$} & EE & EC & \multicolumn{2}{|c|}{ Savings } & \multicolumn{2}{|c|}{$\begin{array}{c}\text { Global Carbon } \\
\text { Savings }\end{array}$} \\
\hline & & & $\begin{array}{l}\left(\mathbf{x 1 0} 0^{9}\right. \\
\text { MJ) }\end{array}$ & $\begin{array}{c}(\mathbf{G t} \\
\left.\mathrm{CO}_{2} \mathrm{e}\right) \\
\end{array}$ & $\mathbf{E E}$ & EC & $\begin{array}{l}(\mathbf{G t} \\
\left.\mathrm{CO}_{2} \mathrm{e}\right) \\
\end{array}$ & $\%$ \\
\hline 250 & $70,842,066$ & 0 & 1,233 & 0.0992 & $0.00 \%$ & $0.00 \%$ & 0.000 & $0.00 \%$ \\
\hline 500 & $38,463,218$ & 21,106 & 680 & 0.0545 & $44.82 \%$ & $45.00 \%$ & 0.045 & $0.123 \%$ \\
\hline \multirow{2}{*}{$\begin{array}{l}\text { Yield } \\
\text { Strength } \\
\text { (MPa) }\end{array}$} & \multirow{2}{*}{ Steel (t) } & \multirow{2}{*}{$\begin{array}{l}\text { Vanadium } \\
\text { (t) }\end{array}$} & $\mathbf{E E}$ & EC & \multicolumn{2}{|c|}{ Savings } & \multicolumn{2}{|c|}{$\begin{array}{c}\text { Global Carbon } \\
\text { Savings }\end{array}$} \\
\hline & & & $\begin{array}{l}(\mathbf{x 1 0})^{9} \\
\text { MJ) }\end{array}$ & $\begin{array}{c}(\mathbf{G t} \\
\left.\mathrm{CO}_{2} \mathrm{e}\right) \\
\end{array}$ & $\mathbf{E E}$ & EC & $\begin{array}{l}(\mathrm{Gt} \\
\left.\mathrm{CO}_{2} \mathrm{e}\right) \\
\end{array}$ & $\%$ \\
\hline 250 & $1,861,452$ & 0 & 32 & 0.0026 & $0.00 \%$ & $0.00 \%$ & 0.000 & $0.00 \%$ \\
\hline 600 & 865,422 & 1,508 & 16 & 0.0013 & $51.11 \%$ & $51.59 \%$ & 0.001 & $0.004 \%$ \\
\hline
\end{tabular}

Table 11: Energy and carbon savings using vanadium in rebar market data (Global) and vanadium amounts weighted by proportion of steel. The steel column denotes the total steel consumption. Both vanadium and steel interpolated using EU data. The EE and EC columns denote the net savings in embodied energy and carbon for 400 and $600 \mathrm{MPa}$ rebar. (Yield strength shown in bold denotes mild steel bar as the baseline)

\begin{tabular}{|c|c|c|c|c|c|c|c|c|}
\hline \multirow{2}{*}{$\begin{array}{l}\text { Yield } \\
\text { Strength } \\
\text { (MPa) }\end{array}$} & \multirow[b]{2}{*}{ Steel $(t)$} & \multirow{2}{*}{$\begin{array}{l}\text { Vanadium } \\
\text { (t) }\end{array}$} & \multirow{2}{*}{$\begin{array}{c}\text { EE } \\
\left(\mathbf{x 1 0}^{9}\right. \\
\text { MJ) }\end{array}$} & \multirow{2}{*}{$\begin{array}{c}\text { EC } \\
(\mathbf{G t} \\
\left.\mathrm{CO}_{2} \mathrm{e}\right)\end{array}$} & \multicolumn{2}{|c|}{ Savings } & \multicolumn{2}{|c|}{$\begin{array}{c}\text { Global Carbon } \\
\text { Savings }\end{array}$} \\
\hline & & & & & EE & EC & $\begin{array}{c}(\mathrm{Gt} \\
\left.\mathrm{CO}_{2 \mathrm{e}}\right)\end{array}$ & $\%$ \\
\hline 250 & $216,656,852$ & 0 & 3,770 & 0.3033 & $0.00 \%$ & $0.00 \%$ & 0.000 & $0.00 \%$ \\
\hline 400 & $142,653,659$ & 6,498 & 2,486 & 0.1999 & $34.07 \%$ & $34.09 \%$ & 0.103 & $0.29 \%$ \\
\hline \multirow{2}{*}{$\begin{array}{l}\text { Yield } \\
\text { Strength } \\
\text { (MPa) }\end{array}$} & \multirow{2}{*}{ Steel (t) } & \multirow{2}{*}{$\begin{array}{l}\text { Vanadium } \\
\text { (t) }\end{array}$} & EE & EC & \multicolumn{2}{|c|}{ Savings } & \multicolumn{2}{|c|}{$\begin{array}{l}\text { Global Carbon } \\
\text { Savings }\end{array}$} \\
\hline & & & $\begin{array}{l}\left(\mathbf{x 1 0}{ }^{9}\right. \\
\text { MJ) }\end{array}$ & $\begin{array}{c}(\mathbf{G t} \\
\left.\mathrm{CO}_{2} \mathbf{e}\right)\end{array}$ & $\mathbf{E E}$ & EC & $\begin{array}{c}(\mathbf{G t} \\
\left.\mathrm{CO}_{2} \mathbf{e}\right)\end{array}$ & $\%$ \\
\hline 250 & $46,632,828$ & 0 & 811 & 0.0653 & $0.00 \%$ & $0.00 \%$ & 0.000 & $0.00 \%$ \\
\hline 600 & $21,680,441$ & 13,447 & 384 & 0.0308 & $52.65 \%$ & $52.83 \%$ & 0.034 & 0.095 \\
\hline
\end{tabular}




\section{Discussion}

The steel industry is a leading contributor to global carbon emissions with a carbon footprint that is not readily amenable to reduction through technology innovations. It is estimated that ca. $22.5 \%$ of global steel production goes towards reinforcement bars used in the construction industry ("Steel In Buildings and Infrastructure," 2020). In this paper, we have investigated the reduction of the embodied energy and carbon footprint of steel reinforcement bars resulting from vanadium microalloying. The incorporation of small quantities of vanadium effects large increases in yield strength. A machine learning model is developed to identify specific alloy compositions from aggregated data and provide an unambiguous view of the dependence of yield strength on vanadium concentration (Figure 3 and Table 2). The increased strength of vanadium microalloyed steels translates to substantial material savings in comparison to lower grade rebar. Material savings in turn translate to a reduction in embodied carbon and embodied energy of individual reinforced concrete structural elements (from $0.67 \%$ reduction in the carbon footprint of a RC slab (600 $\mathrm{MPa}$ steel) to $40.40 \%$ reduction in the carbon footprint of a RC beam (600 MPa steel), Table 4$)$ as well as entire buildings (26.26\% reduction embodied energy and $18.83 \%$ reduction in embodied carbon for a hypothetical building (600 MPa steel), Table 5) after debiting the energy and carbon costs associated with vanadium incorporation.

The reduction in carbon footprint deduced from the life-cycle assessment of the compositions with different vanadium content can be extrapolated using vanadium consumption data to obtain cumulative metrics on the role of microalloying in reducing regional and global greenhouse emissions. Granular and segmented market data is available for China given the recent adoption of new reinforcement bar standards. Impact assessment suggests that vanadium microalloying results in a ca. $1.01 \%$ reduction of total fossil carbon footprint (range of $0.18 \%$ 
$1.15 \%)$ in China. The EU market is considerably more diverse in terms of rebar grades and has a much lower consumption of vanadium. Nevertheless, ca. $0.19 \%$ reduction of total fossil carbon footprint (range of $0.07-0.42 \%$ ) is estimated in the EU. Global figures extrapolated from worldwide vanadium consumption with China and EU intensity of vanadium use in rebar as boundary conditions denote $0.377-0.385 \%$ reduction of total global fossil carbon footprint, attesting to the significant role that vanadium plays in enhancing the sustainability of the steel industry.

\section{Conclusions and Policy Implications}

The construction industry represents a substantial burden on limited natural resources and has a massive global carbon footprint that derives in large measure from the embodied energy and carbon costs of building materials. Steel reinforcement bars are ubiquitous in reinforced concrete structures, and indeed half of global steel production goes towards the construction of buildings and infrastructure. Methods to increase the strength-to-weight ratio of steel through control of microstructure achieved through alloying or grain refinement hold considerable promise for reducing the amount of steel required to attain a specific load-bearing capacity. In this study, we have evaluated the carbon footprint of vanadium-microalloyed steel of different grades with

respect to mild steel in terms of both embodied energy and carbon. A comprehensive accounting of the costs and benefits of vanadium microalloying demonstrates the critical (often underappreciated) role that vanadium plays in enhancing the sustainability of the steel industry as well as the construction industry. The impact of vanadium microalloying is estimated to be $0.377-0.385 \%$ of the total global fossil carbon footprint.

This work demonstrates that the impact of construction materials can be dramatically reduced by supplanting lower grade products with higher value alternatives. A life cycle focus is 
imperative for decisions that occur at the intersection of policy, energy, and the environment. The devastation wrought by the 2008 Sichuan earthquake in China caused a major rethink of rebar standards for building construction. While a perhaps an unintended benefit, the implementation of a new rebar policy has accrued significant $\mathrm{CO}_{2}$ savings evidencing the importance of a life cycle perspective on building materials in a circular economy.

The efficacy of vanadium in reducing embodied energy and carbon footprint is directly traceable to two specific attributes. First, as a result of the co-production of vanadium with steel and the substantial amount of vanadium extracted from recycled slag and spent catalysts, the energy and carbon costs associated with vanadium production are relatively low (Table 3); future projections suggest as much as a threefold reduction in the embodied carbon costs of vanadium production may be attainable with adoption of specific technology improvements (BlackRock Metals: Life Cycle Assessment of Vanadium, 2014). Second, vanadium addition increases yield strength at relatively low concentrations (e.g., as compared to niobium) and at low processing temperatures as a result of the intrinsic miscibility of the two elements in the Fe- $\mathrm{V}$ phase diagram. As such, policy interventions seeking to reduce the carbon footprint of the steel and construction industries must take into account the distinctive and often outsized role of microalloying elements. The framework developed here informed by machine learning of data aggregated from the published literature, structural modeling in concordance with established building codes, life cycle assessment based on databases, and tonnage data obtained from trade organizations provides a blueprint for assessing the role of specific alloying elements in enhancing the sustainability of the steel industry. 


\section{Acknowledgements}

The authors are grateful to Vanitec for support of this work. We further acknowledge partial support of this work from the X-Grants Program: A President's Excellence Fund Initiative at Texas A\&M University. D.A.S. acknowledges support under a NSF Graduate Research Fellowship under grant No. 1746932.

\section{References}

American Iron and Steel Institute, 2016. Profile 2016.

Babakhani, A., Kiani-Rashid, A.R., Ziaei, S.M.R., 2012. The microstructure and mechanical properties of hot forged vanadium microalloyed steel. Mater. Manuf. Process. 27, 135-139. https://doi.org/10.1080/10426914.2011.557287

Bajpayee, A., Farahbakhsh, M., Zakira, U., Pandey, A., Ennab, L.A., Rybkowski, Z., Dixit, M.K., Schwab, P.A., Kalantar, N., Birgisson, B., Banerjee, S., 2020. In situ Resource Utilization and Reconfiguration of Soils Into Construction Materials for the Additive Manufacturing of Buildings. Front. Mater. 7, 1-12. https://doi.org/10.3389/fmats.2020.00052

Baker, T.N., 2016. Microalloyed steels. Ironmak. Steelmak. 43, 264-307. https://doi.org/10.1179/1743281215Y.0000000063

Baker, T.N., 2009. Processes, microstructure and properties of vanadium microalloyed steels. Mater. Sci. Technol. 25, 1083-1107. https://doi.org/10.1179/174328409x453253

Baker, T.N., Baker, T.N., 2016. Microalloyed steels Microalloyed steels 9233. https://doi.org/10.1179/1743281215Y.0000000063

Bauer, G., 2012. Vanadium and Vanadium Compounds. Ullmanns Encycl. Ind. Chem. 37, 425474. https://doi.org/10.1002/14356007.a27

Beatty, J., 2011. Vanadium Strong and Army Strong: Strength Matters! AMMTIAC Q. 6, 3-14. https://doi.org/10.1017/CBO9781107415324.004

Bechthold, M., Weaver, J.C., 2017. Materials science and architecture. Nat. Rev. Mater. https://doi.org/10.1038/natrevmats.2017.82

BlackRock Metals: Life Cycle Assessment of Vanadium, 2014.

Braham, E.J., Cho, J., Forlano, K.M., Watson, D.F., Arròyave, R., Banerjee, S., 2019. Machine 
Learning-Directed Navigation of Synthetic Design Space: A Statistical Learning Approach to Controlling the Synthesis of Perovskite Halide Nanoplatelets in the Quantum-Confined Regime. Chem. Mater. 31, 3281-3292. https://doi.org/10.1021/acs.chemmater.9b00212

British Standards Institute, 2005. Steel for the reinforcement of concrete - Weldable reinforcing steel - General.

BS 4449:1997, 1997. Specification for carbon steel bars for the reinforcement of concrete.

Bushveld, 2018. Vanadium 101.

Chen, C.Y., Yen, H.W., Kao, F.H., Li, W.C., Huang, C.Y., Yang, J.R., Wang, S.H., 2009. Precipitation hardening of high-strength low-alloy steels by nanometer-sized carbides. Mater. Sci. Eng. A 499, 162-166. https://doi.org/10.1016/J.MSEA.2007.11.110

China's inspections to speed up rebar standards rollout [WWW Document], 2019. . Arg. Media. URL https://www.argusmedia.com/en/news/1829554-chinas-inspections-to-speed-up-rebarstandards-rollout

Copiello, S., 2016. Economic implications of the energy issue : Evidence for a positive non-linear relation between embodied energy and construction cost. Energy Build. 123, 59-70. https://doi.org/10.1016/j.enbuild.2016.04.054

Crooks, M.J., Miner, R.E., 1996. The Ultralight Steel Auto Body program completes phase I. JOM 48, 13-15. https://doi.org/10.1007/BF03222987

Data provided by VANITEC Market Development Committee, 2019.

Davies, P.J., Emmitt, S., Firth, S.K., 2014. Challenges for capturing and assessing initial embodied energy : a contractor' s perspective Challenges for capturing and assessing initial embodied energy: a contractor ', s perspective. Constr. Manag. Econ. 32, 290-308. https://doi.org/10.1080/01446193.2014.884280

Deping, G., Mingxing, H., Kaijin, L., 2000. Application of VN Alloy in 400MPa Reinforcing Bar.

Dixit, M.K., 2019. Life cycle recurrent embodied energy calculation of buildings : A review. J. Clean. Prod. 209, 731-754. https://doi.org/10.1016/j.jclepro.2018.10.230

Dixit, M.K., 2017. Life cycle embodied energy analysis of residential buildings : A review of literature to investigate embodied energy parameters. Renew. Sustain. Energy Rev. 79, 390413. https://doi.org/10.1016/j.rser.2017.05.051

EN 1990:2002+A1, 2005. Eurocode - Basis of structural design.

EN 1991-1-1, 2002. Eurocode 1: Actions on structures - Part 1-1: General actions - Densities, selfweight, imposed loads for buildings. 
EN 1991-1-4, 2010. Eurocode 1: Actions on structures - Part 1-4: General actions - Wind actions.

EN 1992-1-1, 2004. Eurocode 2: Design of concrete structures - Part 1-1: General rules and rules for buildings.

EN 1997-1, 2004. Eurocode 7: Geotechnical design - Part 1: General rules.

EN 206-1, 2000. Concrete Part - 1: Specification, performance, production and conformity.

G.Davies, R., 1978. The deformation behavior of a vanadium-strengthened dual phase steel. Metall. Trans. A 9, 41-52. https://doi.org/10.1007/BF02647169

Garcia, C.I., 2016. High strength low alloyed (HSLA) steels, Automotive Steels: Design, Metallurgy, Processing and Applications. Elsevier Ltd. https://doi.org/10.1016/B978-0-08100638-2.00006-7

Global Carbon Budget, 2018. Global Carbon Project [WWW Document]. Open access Earth Syst. Sci. Data. URL https://www.globalcarbonproject.org/carbonbudget/archive/2018/GCP_CarbonBudget_201 8.pdf

Glodowski, R.J., 2014. An Updated Prediction Model for Vanadium Precipitation Strengthening of Ferritic Steels.

Guardigli, L., 2014. Comparing the environmental impact of reinforced concrete and wooden structures. https://doi.org/10.1533/9780857097729.3.407

Gündüz, S., Cochrane, R.C., 2005. Influence of cooling rate and tempering on precipitation and hardness of vanadium microalloyed steel. Mater. Des. 26, 486-492. https://doi.org/10.1016/j.matdes.2004.07.022

Hammond, G., Jones, C., 2011. Inventory of Carbon \& Energy (ICE) Version 2.0. UK.

Hasanbeigi, A., Price, L., Lin, E., 2012. Emerging energy-efficiency and CO 2 emission-reduction technologies for cement and concrete production: A technical review. Renew. Sustain. Energy Rev. https://doi.org/10.1016/j.rser.2012.07.019

Houvilla, P., 2007. Buildings and Climate Change: Current Status, Challenges and Opportunities. United Nation Environ. Program. 1-88.

Korchynsky, M., Paules, J.R., 1989. Microalloyed forging steels-A state of the art review, in: SAE Technical Papers. https://doi.org/10.4271/890801

Levin, K., 2018. New Global CO2 Emissions Numbers: They're Not Good [WWW Document]. World Resour. Inst. Artic. URL https://www.wri.org/blog/2018/12/new-global-co2emissions-numbers-are-they-re-not-good 
Li, Y., Milbourn, D., 2015. The influence of vanadium microalloying on the production of thin slab casting and direct rolled steel strip. 7th Int. Conf. High Strength Low Alloy Steels, HSLA Steels 2015, Int. Conf. Microalloying 2015, Microalloying 2015 Int. Conf. Offshore Eng. Steels 2015, OES 2015 1, 343-349. https://doi.org/10.1007/978-3-319-48767-0_38

Lv, Y., Sheng, G., Jiao, Y., 2014. Effect of V/N ratio on the high strain and low cycle fatigue behaviors of V-N microalloyed rebars. Constr. Build. Mater. 69, 18-25. https://doi.org/10.1016/J.CONBUILDMAT.2014.06.047

Meyer, D., Dimitriadou, E., Hornik, K., Weingessel, A., Leisch, F., 2017. e1071: Misc Functions of the Department of Statistics, Probability Theory Group (Formerly: E1071), TU Wien.

Milbourn, D., Yu, L., 2010. Metallurgical Benefits of Vanadium Microalloying in Producing High Strength Seismic Grade Rebar. Int. Semin. Prod. Appl. HIgh Strength Seism. Grade Rebar Contain. Vanadium 32-43.

Milbourn, D., Yu, L., Copiello, S., Davies, P.J., Emmitt, S., Firth, S.K., 2010. Metallurgical Benefits of Vanadium Microalloying in Producing High Strength Seismic Grade Rebar. Int. Semin. Prod. Appl. HIgh Strength Seism. Grade Rebar Contain. Vanadium 68, 32-43. https://doi.org/10.1680/ener.2008.161.2.87

Montemarano, T.W., Sack, B.P., Gudas, J.P., Vassilaros, M.G., Vanderveldt, H.H., 1986. High Strength Low Alloy Steels in Naval Construction. J. Sh. Prod. 2, 145-162.

Moynihan, M.C., Allwood, J.M., 2012. Resources, Conservation and Recycling The flow of steel into the construction sector. "Resources, Conserv. Recycl. 68, 88-95. https://doi.org/10.1016/j.resconrec.2012.08.009

Nakoryakova, L., Kasatkin, D., Afanasyeva, Y., 2019. Overview of the steel and iron ore market.

Parija, A., Waetzig, G.R., Andrews, J.L., Banerjee, S., 2018. Traversing Energy Landscapes Away from Equilibrium: Strategies for Accessing and Utilizing Metastable Phase Space. J. Phys. Chem. C 122, 25709-25728. https://doi.org/10.1021/acs.jpcc.8b04622

Patel, J., 2018. China Steel Rebar : Market Overview and Latest Product Developments.

Plank, R., 2008. The principles of sustainable construction. IES J. Part A Civ. Struct. Eng. 1, 301307. https://doi.org/10.1080/19373260802404482

Rehder, D., 2015. The role of vanadium in microalloyed steels. Metallomics 7, 730-742. https://doi.org/10.1039/c4mt00304g

Sage, A.M., 1984. Vanadium in structural steels 84, 138-146.

Sage, A.M., 1976. Effect of V, N and Al on the Mechanical Properties of Reinforcing Bar Steels. Met. Technol. 3, 65-70. 
Shihuai, S., Weiguo, W., Ruoqiang, Z., Mingqi, Z., Ying, W., 2003. The Commercial Trial Production of HRB400 reinforced bar with V-N Microalloying. Int. Symp. Res. Appl. High Strength Reinf. Bar 110-114.

Show, B.K., Veerababu, R., Balamuralikrishnan, R., Malakondaiah, G., 2010. Effect of vanadium and titanium modification on the microstructure and mechanical properties of a microalloyed HSLA steel. Mater. Sci. Eng. A https://doi.org/10.1016/J.MSEA.2009.10.049

Skobir, D.A., 2011. High-strength low-alloy (HSLA) steels: Visokotrdna malolegirana (HSLA) konstrukcijska jekla. Mater. Tehnol. 45, 295-301.

Smith, V., Gard, D., Keoleian, G., 2002. Ultra Light Steel Auto Body Advanced Vehicle Concepts Report No . CSS02-06.

Steel for the Reinforcement of Concrete-Weldable Reinforcing Steel-Bar, Coil and Decoiled Product - Specification, 2005.

Steel In Buildings and Infrastructure [WWW Document], 2020. . worldsteel Assoc. URL https://www.worldsteel.org/steel-by-topic/steel-markets/buildings-and-infrastructure.html (accessed 4.6.20).

Suykens, J.A.K., Vandewalle, J., 1999. Least squares support vector machine classifiers. Neural Process. Lett. https://doi.org/10.1023/A:1018628609742

Synthesis, L.C.A. of M.A.S., 2014. Life Cycle Assessment of Metals: A Scientific Synthesis. PLoS One 9, 1-12. https://doi.org/10.1371/journal.pone.0101298

Taylor, K.A., 1995. Solubility products for titanium-, vanadium-, and niobium-carbide in ferrite. Scr. Metall. Mater. 32, 7-12. https://doi.org/10.1016/S0956-716X(99)80002-8

U.S. Department of Energy, 2008. Energy Efficiency Trends in Residential and Commercial Buildings. Energy.

U.S. Energy Information Administration (EIA), 2020. How much energy is consumed in U.S. residential and commercial buildings?

U.S. Forest Service, 2020. Trees [WWW Document]. URL https://www.fs.usda.gov/learn/trees (accessed 7.30.20).

Vanadium: New Chinese rebar standards positive for ferrovanadium demand [WWW Document], 2018. URL https://roskill.com/news/vanadium-new-chinese-rebar-standards-positiveferrovanadium-demand/\#: :text=for ferrovanadium demand-,Vanadium\%3A New Chinese rebar standards positive for ferrovanadium demand,of inferior steels in construction.\&text=These will re 
Wang, P., Li, Z., Lin, G., Zhou, S., Yang, C., Yong, Q., 2018. Influence of vanadium on the microstructure and mechanical properties of medium-carbon steels for wheels. Metals (Basel). 8, 1-14. https://doi.org/10.3390/met8120978

Weber, S., Peters, J.F., Baumann, M., Weil, M., 2018. Life Cycle Assessment of a Vanadium Redox Flow Battery. Environ. Sci. Technol. 52, 10864-10873. https://doi.org/10.1021/acs.est.8b02073

World Steel Associaiton, 2018. Steel Statistical Yearbook 2018.

World Steel Association, 2018. World Steel in Figures 2018.

Xie, Z.J., Fang, Y.P., Han, G., Guo, H., Misra, R.D.K., Shang, C.J., 2014. Structure-property relationship in a $960 \mathrm{MPa}$ grade ultrahigh strength low carbon niobium-vanadium microalloyed steel: The significance of high frequency induction tempering. Mater. Sci. Eng. A 618, 112-117. https://doi.org/10.1016/j.msea.2014.08.072

Yongquan, Z., Caifu, Y., Shuping, L., 1998. Study of V-N Microalloyed Steels for Reinforcing Bars.

Zajac, S., Siwecki, T., Hutchinson, W.B., Lagneborg, R., 1998. Strengthening mechanisms in vanadium microalloyed steels intended for long products. ISIJ Int. https://doi.org/10.2355/isijinternational.38.1130 